\title{
PENINGKATAN KEMAMPUAN PEMECAHAN MASALAH MATEMATIKA MELALUI MODEL PEMBELAJARAN PROBLEM BASED INSTRUCTION PADA POKOK BAHASAN BANGUN RUANG
}

\author{
Anggi Saputri \\ SD Negeri 1 Kalibagor, Purwokerto, Indonesia \\ email: anggi.sapu3@gmail.com
}

\begin{abstract}
This research was aimed at improvingthe students' mathematic problem solving competence through Problem-Based Instruction (PBI). The subject of this research was IV graders od SD Negeri 1 Kalibagor consisting of 18 males and 19 females. The design of this research was Classroom Action Research which was carried out in 2 cycles in which every cycle consisted of 2 meetings. In each cycle there were planning, acting, observing, and reflecting. The result of the research indicated that the implementation of learning mathematic through Problem- Based Instruction learning model could enhance the mathematic problem solving competence. This was proven by the increaseof the average score of mathematic problem solving competence. The average score inthe first cycle was 14.21 which was considered goog, and in the second cycle it was 16.69 which belonged to very good criteria. The average result of students' mathematic problem soving competencetest was 71.03 in the first cycle and 83.51 in the second cycle. Furthermore, the students' learning mastery was $51.40 \%$ in the first cycle and $89.19 \%$ in the second cycle whic indicated an improvement/
\end{abstract}

Keyword: Mathematic problem solving competence, problem based instruction learning.

\begin{abstract}
Abstrak. Penelitian ini bertujuan untuk meningkatkan kompetensi pemecahan masalah matematika siswa melalui Problem-Based Instruction (PBI). Subjek penelitian ini adalah siswa kelas IV di SD Negeri 1 Kalibagor yang terdiri dari 18 laki-laki dan 19 perempuan. Desain penelitian ini adalah Penelitian Tindakan Kelas yang dilaksanakan dalam 2 siklus dimana setiap siklus terdiri dari 2 pertemuan. Dalam setiap siklus ada perencanaan, tindakan, pengamatan, dan refleksi. Hasil penelitian menunjukkan bahwa penerapan pembelajaran matematika melalui model pembelajaran Problem-Based Instruction dapat meningkatkan kompetensi pemecahan masalah matematika. Ini dibuktikan dengan peningkatan skor ratarata kompetensi pemecahan masalah matematika. Skor rata-rata dalam siklus pertama adalah 14,21 yang dianggap baik, dan pada siklus kedua adalah 16,69 yang termasuk dalam kriteria sangat baik. Hasil ratarata dari masalah matematika siswa yang mampu bersaing adalah 71,03 pada siklus pertama dan 83,51 pada siklus kedua. Selanjutnya, penguasaan belajar siswa adalah $51,40 \%$ pada siklus pertama dan $89,19 \%$ pada siklus kedua yang menunjukkan peningkatan.
\end{abstract}

Kata kunci: Kompetensi pemecahan masalah matematika, pembelajaran berbasis masalah.

\section{PENDAHULUAN}

Mata pelajaran matematika pada jenjang sekoah dasar memuat konsep-konsep dasar matematika yang bertujuan untuk membekali peserta didik dengan kemampuan berpikir logis, analitis dan sistematis.mata pelajaran matematika tidak hanya diberikan untuk meningkatkan kekmampuan berhitung, tetapi juga diberikan untuk meningkatkan kemampuan siswa dalam memecahkan masalah, baik masalah matematika maupun masalah nyata yang menggunakan matematika untuk memecahkannya. Hal ini sesuai dengan BSNP 2006 yaitu agar siswa memiliki kemampuan pemahaman konsep, penalaran, 
memecahkan masalah, mengkomunikasikan gagasan, dan memiliki sikap menghargai kegunaan matematika dalam kehidupan sehari-hari.

Berdasarkan hasil wawancara dengan guru, kemampuan siswa dalam memecahkan masalah matematika masih kurang. Keaktifan siswa dalam berdiskusi juga masih kurang. Hal ini ditandai dengan hasil observasi yang dilakukan terlihat masih banyak siswa yang tidak katif dalam berdiskusi, hanya anak-anak yang pandai yang aktif mengerjakan soal yang diberikan guru. selain itu, didapt juga bahwa pembelajaran masih menggunakan pembelajaran yang masih konvensional dan guru sangat dominan.

Rendahnya kemampuan pemecahan masalah matematika mempengaruhi prestasi belajar siswa. Dari hasil ujian semester ganjil tahun ajaran 2013/2014 menunjukan bahwa prestasi belajar siswa pada mata pelajaran matematika masih rendah hanya $36 \%$ siswa yang tuntas sedangkan $64 \%$ siswa belum tuntas memenuhi KKM yaitu 75. Penggunaan model pembelajaran yang kurang sesuai dengan kondisi dan kemampuan siswa mempengaruhi kemampuan pemecahan masalah matematika karena dalam pembelajaran siswa kurang aktif. Penggunaan model pembelajaran Problem Based Intruction (PBI) dirasa tepat untuk meningkatkan kemampuan pemecahan masalah matematika siswa karena pembelajaran melibatkan siswa secara aktif dalam pembelajaran sehingga pengetahuan yang diperoleh benar-benar diserap baik oleh siswa. Selain itu, siswa juga akan dilatih bekerjasama dengan siswa lainnya.

Solso dkk (2007:434), pemecahan masalah adalah suatu pemikiran yang terarah secara langsung uuntuk menemukan suatu solusi/jalan keluar untuk suatu masalah yang spesifik. Menurut Aisyah, dkk (2008:5-4), pemecahan masalah dalam pengajaran matematika dapat diartikan sebagai penggunaan berbagai konsep, prinsip, dan keterampilan matematika yang telah atau sedang dipelajari untuk menyelesaikan soal non rutin.

Problem Based Instruction (PBI) memusatkan pada masalah kehidupannya yang bermakna bagi siswa, peran guru menyajikan masalah, mengajukan pertanyaan dan memfasilitasi penyelidikan dan dialog (Komalasari, 2011:59). Menurut Nurhadi (2004:109), PBI merupakan model pembelajaran yang menggunakan masalah dunia nyata sebagai suatu konteks untuk belajar tentang cara berpikir kritis dan keterampilan pemecahan masalah, serta memperoleh pengetahuan dan konsep yang esensial dari mata pelajaran. Masalah yang digunakan adalah masalah yang ada di sekitar kehidupan nyata siswa.

Hariwijaya (2009:29) menyebutkan bahwa matematika secara umum didefinisikan sebagai bidang ilmu yang mempelajari pola struktur, perubahan dan ruang.Dalam pandangan formalitas, matematika adalah penelaah struktur abstrak yang didefinisikan secara aksioma dengan menggunakan logika simbolik dan notasi.

Tujuan dari penelitian ini adalah untuk mengetahui peningkatan kemampuan pemacahan masalah matematika setelah menggunakan model pembelajaran Problem Based Istruction(PBI) di kelas IV SD Negeri 1 Kalibagor.

\section{METODE PENELITIAN}

Penelitian yang digunakan adalah Penelitian Tindakan Kelas (PTK). Empat tahapan dalam PTK yaitu perencanaan, 
tindakan, observasi dan refleksi. Penelitian dilakukan dalam dua siklus yang masingmasing siklus terdiri dari dua pertemuan. Subjek penelitian adalah siswa kelas IV SD Negeri 1 Kalibagor tahun ajaran 2013/2014 yang berjumlah 37 siswa yang terdiri dari 18 siswa laki-laki dan 19 siswa perempuan.

Teknik pengumpulan data yang digunakan dalam PTK diperoleh dengan cara tes, observasi dan wawancara. Tes digunakan untuk mengukur kemampuan pemecahan masalah siswa. observasi dilakukan untuk melihat aktivitas guru dan siswa selama proses pembelajaran berlangsun

\section{HASIL DAN PEMBAHASAN}

Berdasarkan proses pembelajaran pada siklus I dan siklus II menggunakan model pembelajaran Problem Based Instruction maka diperoleh hasil sebagai berikut:

1. Kemampuan Pemecahan Masalah Matematika Siswa

Kemampuan pemecahan masalah matematika siswa kelas IV SD Negeri 1 Kalibagor mnegalami peningkatan dari siklus I ke siklus II. Peningkatan rata-rata skor tes kemampuan pemecahan masalah matematika dapat dilihat pada Tabel 1.

Berdasarkan Tabel dapat dilihat bahwa ada peningkatan pada setiap aspek kemampuan pemecahan masalah matematika.

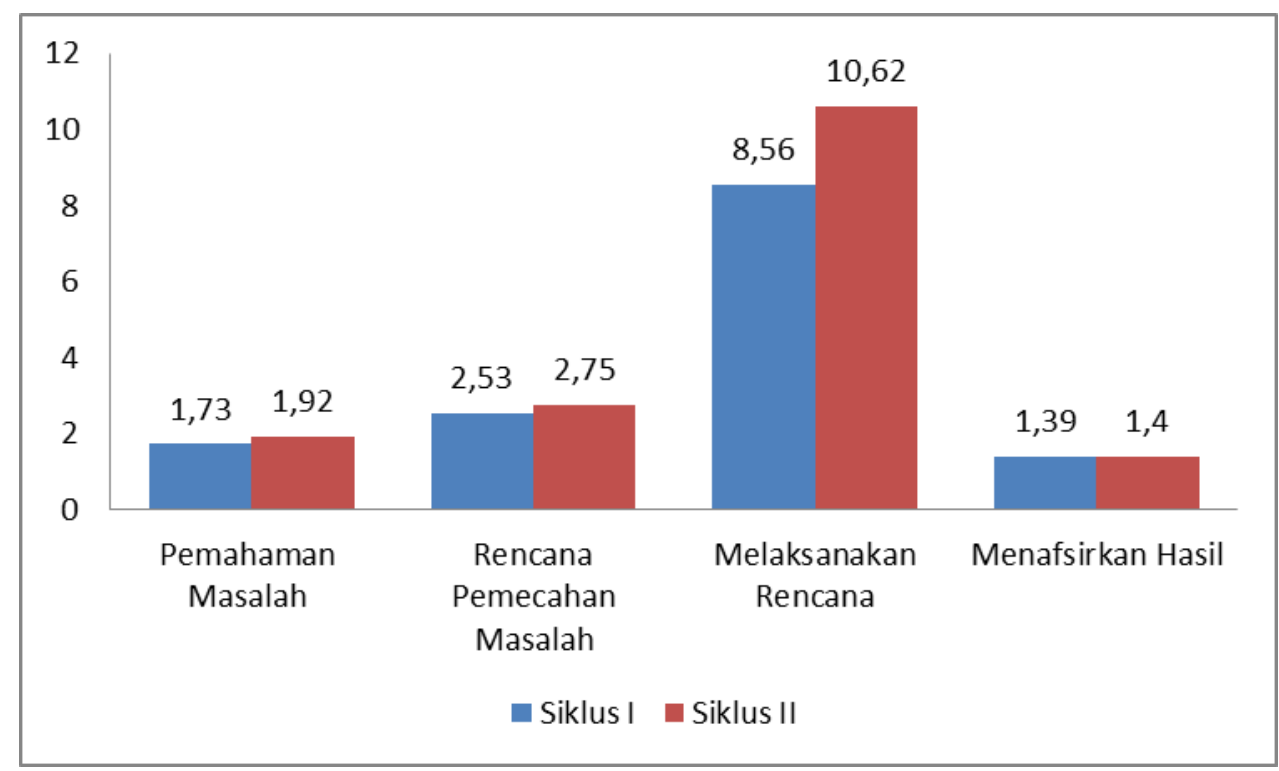

Gambar 1. Histogram Peningkatan Skor Tes Kemampuan Pemecahan Masalah Matematika Siswa

Pada indikator yang pertama yaitu pemahaman masalah mengalami peningkatan dari 1,73 menjadi 1,92 pada siklus II. Sedangkan untuk rencana pemecahan masalah siswa dari skor 2,52 menjadi 2,75 . Untuk indikator yang ketiga yaitu melaksanakan rencana terjadi peningkatan dari 8,56 menjadi 10,62 pada siklus II dan untuk indikator yang terakhir adalah menafsirkan hasil terjadi peningkatan dari 1,39 menjadi 1,40. Secara keseluruhan, rata-rata total indikator pada siklus I adalah 14,21 dengan kriteria baik 
mengalami peningkatan pada siklus II menjadi 16,69 dengan kriteria sangat baik. Rekapitulasi nilai tes kemampuan pemacahan masalah matematika siswa juga meningkat. Hasil rekapitulasi nilai tes kemampuan pemecahan masalah matematika siswa dapat dilihat pada Tabel 1 .

Tabel 2

Hasil Rekapitulasi Nilai Tes Kemampuan Pemecahan Masalah Matematika Siswa Siklus I dan Siklus II

\begin{tabular}{|c|l|c|c|}
\hline No. & \multicolumn{1}{|c|}{ Indikator } & Siklus I & Siklus II \\
\hline 1. & Nilai tertinggi & 95 & 100 \\
\hline 2. & Nilai terendah & 20 & 40 \\
\hline 3. & Rata-rata nilai & 71,03 & 83,51 \\
\hline 4. & Siswa tuntas belajar & 19 & 33 \\
\hline 5. & Persentase & $51,40 \%$ & $89,19 \%$ \\
\hline 6. & Siswa Tidak tuntas belajar & 18 & 4 \\
\hline 7. & Persentase & $48,60 \%$ & $10,81 \%$ \\
\hline
\end{tabular}

Tabel 2 menunjukan bahwa rata-rata nilai tes kemampuan pemecahan matematika dari siklus I meningkat pada siklua II dengan nilai rata-rata 71,03 menjadi 83,51. Hasil ketuntasan belajar siswa meningkat. Pada siklus I jumlah siswa ynag tuntas dalam belajar sebanyak 19 siswa dengan pesentase $51,40 \%$, sedangkan pada siklus II jumlah siswa yang tuntas bertmabh menjadi 33 siswa dengan persentase $89,19 \%$ pada siklus II.
Jumlah siswa yang tidak tuntas menurun menjadi sebanyak 4 siswa pada siklus II. Pesebtase siswa yang tidak tunatas pada siklus I sebesar 48,50\% menurun menjadi $10,81 \%$ pada siklus II.

2. Peningkatan Aktivitas Guru

Hasil peningkatan obeservasi aktivitas guru dapat dilihat Tabel 2.

Tabel 3

\section{Peningkatan Aktivitas Guru}

\begin{tabular}{|c|c|}
\hline \\
\hline SIKLUS I & SIKLUS II \\
\hline $\begin{array}{l}\text { Guru belum memberikan perma-salahan } \\
\text { tentang kehidupan sehari-hari yang } \\
\text { berkaitan dengan materi. }\end{array}$ & $\begin{array}{l}\text { Guru memberikan permasalahan tentang } \\
\text { kehidupan sehari-hari yang berkaitan } \\
\text { dengan materi. }\end{array}$ \\
\hline $\begin{array}{l}\text { Guru belum memberikan kesempatan } \\
\text { kepada siswa untuk menuliskan } \\
\text { kesimpulan pada akhir pembelajaran. }\end{array}$ & $\begin{array}{l}\text { Guru memberikan kesempatan kepada } \\
\text { siswa untuk menuliskan kesimpulan } \\
\text { pada akhir pembelajaran. }\end{array}$ \\
\hline $\begin{array}{l}\text { Guru belum memaksimalkan alokasi } \\
\text { waktu yang ada pada pembelajaran } \\
\text { sehingga ada beberapa langkah dalam } \\
\text { pembelajaran yang tidak diberikan oleh } \\
\text { guru kepada siswa. }\end{array}$ & $\begin{array}{l}\text { Guru memaksimalkan alokasi waktu } \\
\text { yang ada pada pembelajaran sehingga } \\
\text { langkah-langkah dalam pembelajaran } \\
\text { dapat terlaksana denagn baik }\end{array}$ \\
\hline $\begin{array}{l}\text { Guru belum memberikan kesempatan } \\
\text { kepada semua kelompok untuk } \\
\text { menyajikan hasil diskusi pemecahan } \\
\text { masalah matematika }\end{array}$ & $\begin{array}{l}\text { Guru memberikan kesempatan kepada } \\
\text { semua kelompok untuk menyajikan hasil } \\
\text { diskusi pemecahan masalah matematika }\end{array}$ \\
\hline
\end{tabular}

Berdasarkan tabel di atas, terlihat bahwa aktivitas guru pada siklus I dan siklus II pada pembelajaran matematika pokok bahasan bangun ruang menggunakan pembelajaran model PBI mengalami peningkatan pada setiap siklusnya. 
3. Peningkatan Aktivitas Siswa

Hasil observasi aktivitas siswa pada siklus I dan Siklus II pada pemebalajaran matematika poko bahasan bangun ruang menggunakan model PBI adalah sebagai berikut:

\section{Tabel 4}

\section{Peningkatan Aktivitas Siswa}

\begin{tabular}{|l|l|}
\hline \multicolumn{1}{|c|}{ SIKLUS I dengan kelompoknya } & \multicolumn{1}{c|}{ SIKLUS II } \\
\hline $\begin{array}{l}\text { Siswa diswa bersama-sama dengan } \\
\text { belum bekerja sama dalam } \\
\text { memecahkan masalah matematika } \\
\text { yang ada di LKS. }\end{array}$ & $\begin{array}{l}\text { kelompoknya bekerja sama dalam } \\
\text { memecahkan masalah matematika } \\
\text { yang ada di LKS. }\end{array}$ \\
\hline $\begin{array}{l}\text { Siswa belum aktif dalam } \\
\text { berdiskusi memecahkan masalah } \\
\text { yang ada di LKS. }\end{array}$ & $\begin{array}{l}\text { Terlihat saat berdiskusi sebagian } \\
\text { besar siswa aktif d memecahkan } \\
\text { masalah yang ada di LKS. }\end{array}$ \\
$\begin{array}{l}\text { Beberapa siswa belum berani } \\
\text { bertanya apabila mengalami } \\
\text { kesulitan biswa sudah berani bertanya } \\
\text { Beberapa siswa belum berani } \\
\text { menjadi juru bicara kelompok }\end{array}$ & $\begin{array}{l}\text { Siswa sudah berani menjadi juru } \\
\text { bicara kelompok }\end{array}$ \\
\hline
\end{tabular}

Berdasarkan pembahasan di atas, dapat disimpukan bahwa kemampuan pemecahan masalah matematika siswa di kelas IV SD Negeri 1 Kalibagor dapat ditingkatkan dengan pembelajaran dengan model PBI. Penggunaan model pembelajaran PBI menjadikan siswa lebih paham terhadap materi. Hal ini disebabkan karena pada model PBI menggunakan masalah-masalah dunia nyata dalam kehidupan sehari-hari siswa sehingga siswa dapat lebih mudah menyerap dan memahami materi yang disampaikan guru.

\section{SIMPULAN DAN SARAN}

Berdasarkan hasil PTK ynag dilaksanakan disimpukan:

1. Pelaksanaan pembelajaran matematika dengan menggunakan model pembejaran Problem Based Instruction dapat meningkatkan kemampuan pemecahan masalah matematika.

2. Pembelajaran matematika menggunakan model PBI di kelas IV SD 1 kalibagor mengalami peningkatan pada siklus I rata-rata total skor kemampuan pemecahan masalah matematika adalah 14,21 dengan kriteria "Baik" dan pada siklus II ratarata total skor kemampuan pemecahan masalah matematika sebesar 16,69 dengan kriteria "Sangat Baik".

3. Pembelajaran matematika mealui PBI Pada siklus I hasil rata-rata nilai tes kemampuan pemecahan masalah matematika siswa yaitu sebesar 71,03 meningkat pada siklus II menjadi sebesar 83,51. Selain itu, ketuntasan belajar siswa juga mengalami peningkatan yaitu ketuntasan belajar siswa pada siklus I sebesar 51,40\% menjadi $89,19 \%$ pada siklus II.

\section{DAFTAR PUSTAKA}

Aisyah, Nyimas, dkk. 2008. Pengembangan Pembelajaran Matematika SD. Jakarta: Direktorat Jendral Pendidikan Tinggi Departemen Pendidikan Nasional.

BSNP (Badan Standar Nasional Pendidikan). 2006. Standar Isi 2006 Mata Pelajaran Matematika. Jakarta. Hariwijaya. 2009. Meningkatkan Kecerdasan Matematika. Magelang: Tugu Publisher. 
Anggi Saputri

Komalasari, K. 2011. Pembelajaran Solso, Robert L, dkk. 2007. Psikologi Kontekstual: Konsep dan Aplikasi. Kognitif (edisi delapan). Jakarta: Bandung: PT Refika Aditama Erlang

Nurhadi. 2004. Kurikuluum 2004

Pertanyaan Pertanyaan dan

Jawaban. Jakarta: Grasindo. 